ISBN 978-93-5137-179-3

\title{
Comparative study of own prepared and market available
}

\section{Samples of Gandhaka Rasayana}

\section{Nade Tejaswini Adappa, S.L.Dasari}

1. Asst Professor, Rasashastra Bhaishajyakalpana Department,

2. HOD \& Professor, Dravyaguna Department,

Mob No 9890376949; Email: drsldasari@gmail.com

ASS Aayurved College, Nashik, Maharashtra, India.

*Corresponding Author: Mob No 8452011625; Email : teja_nade@yahoo.com

\section{Abstract:}

Gandhaka Rasayana is a very well known and commonly used Herbo-mineral preparation with Shuddha Gandhaka as its main ingredient processed with various bhavana medias. According to Yoga Ratnakar Gandhaka Rasayan is prepared by giving bhavana of twelve herbal drugs in serial manner for eight times each and finally combined with equal quantity of sugar.

But different pharmacies prepare Gandhaka Rasayana by different procedures according to their ease and feasibility, they write the reference on labeling but they don't prepare it by proper method. The main difference is in the number of Bhavana and the Bhavana dravya used for the preparation. Also the purification of Gandhaka before the procedure may or may not take place properly or the method used for it may be inappropriate

Thus the present study is undertaken to prove the comparison between own prepared and market available samples of Gandhaka Rasayana. Therefore own prepared and three market available samples all of same reference of Yoga Ratnakar were compared by their physico chemical parameters like PH, Ash Value, Sulphur percentage, Particle size etc. Overall, a remarkable difference was observed in the samples of own prepared and market samples of Gandhaka Rasayana.

KEYWORD: Gandhaka Rasayana, bhavana, Sulphur, Chaturjat, Guduchi, Haritaki, Bibhitak 


\section{INTRODUTION:}

Gandhaka Rasayana is a very well known and commonly used medicine. According to Yoga Ratnakar Gandhaka rasayan is prepared by giving bhavana of twelve herbal drugs. It is prepared by giving bhavana to Shuddha Gandhak with following liquids, godugdha, Chaturjata phanta, guduchi swaras, haritaki kwatha, bibhitaki kwatha, amalaki swaras, shunthi kwatha, bhringraj swaras each eight times, and after eighth bhavana of each dravya adraka swaras bhavana, and finally combined with equal quantity of sugar.

Bhavana is a process in which a drug is combined or mixed and triturated with an expressed juice or decoction or any kind of liquid till it totally absorbs that liquid. Bhavana is an important procedure during drug processing affecting the physico chemical characteristics and biological properties of Gandhaka.

But different pharmacies prepare Gandhaka Rasayana by different procedures according to their ease and feasibility. The main difference is in the number of Bhavana and the Bhavana dravya used for the preparation. Also the purification of Gandhaka before the procedure may or may not take place properly or the method used for it may be inappropriate

Thus the present study is undertaken to prove the comparison between own prepared and market available samples of Gandhaka Rasayana.

\section{Aims and objectives:}

Aim
To prepare and standardize Gandhaka Rasayana and to carry out its comparative study with market available samples of Gandhak Rasayana.

\section{Objectives:}

- To perform Gandhaka Shodhana according to Rasa Tarangini $8 / 21$ 22

- To prepare Gandhaka Rasayana as per method described in Yog Ratnakar Rasayanadhikar.

- To study the physico chemical characteristics of Gandhaka Rasayana.

- To compare own prepared and market available samples of Gandhaka Rasayana.

\section{Materials And Methods}

\section{Gandhaka Shodhana}

Gandhaka powder was put in iron utensil and heated till it melted completely, the bhringaraja swaras was taken in a container up to its brim. The melted Gandhaka poured into bhringaraja swaras container covered with muslin cloth. The sulphur solidified at the base of container was collected and washed with hot water. The procedure was repeated six more times with fresh bhringaraja swaras each time and washed with hot water. Thus Gandhaka was purified.

\section{Preparation of Gandhaka Rasaayana}

The electric machine End runner was used to give bhavana, following Bhavana are given to shuddha Gandhaka, Five hundred grams of Gandhaka was powdered and put in end runner, Godugdha is added in quantity so as to completely immerse the Gandhak, Bhavana was carried out continuously for two hours. After 
complete drying again sufficient amount of godugdha was added for second Bhavana, Likewise eight bhavanas were given and this is followed by eight Bhavana of Chaturjat Phanta, eight bhavana of Guduchi Swaras, eight Bhavana of Haritaki Kwatha, eight Bhavana of Bibhitak Kwatha, eight Bhavana of Aamlaki swaras, eight Bhavana of Shunthi Kwatha, eight Bhavana of Bhringaraj Swaras and after eighth Bhavana of each Observation And Results dravya Aadraka swaras Bhavana was given. After all the Bhavana same quantity of Sugar was added to the mixture.

Physico chemical analysis of All samples of Gandhaka Rasayana

All three Market samples and this sample of Gandhaka Rasayana were analyzed, and their Ash Value, Particle Size, PH value, Sulphur percentage, Water soluble Extract And TLC, these tests are done.

Table 1. Physico chemical Analysis

\begin{tabular}{|l|c|c|c|c|}
\hline \multicolumn{1}{|c|}{ Parameters } & $\begin{array}{c}\text { Lab prepared } \\
\text { sample }\end{array}$ & $\begin{array}{c}\text { Market } \\
\text { Sample 1 }\end{array}$ & $\begin{array}{c}\text { Market } \\
\text { Sample 2 }\end{array}$ & $\begin{array}{c}\text { Market } \\
\text { Sample 3 }\end{array}$ \\
\hline Loss on drying & 1.91 & 2.72 & 3.51 & 3.3 \\
\hline pH & 4.45 & 5.6 & 4.42 & 6.4 \\
\hline Ash Value \% & 25 & 35.5 & 39 & 33 \\
\hline Sulphur \% & 13.74 & 53.51 & 19.24 & 70.08 \\
\hline Water soluble extract & 48.84 & 25.95 & 34.10 & 6.79 \\
\hline Particle size (mm) & $<0.841$ & $<1.41$ & $<1.68$ & $<1.00$ \\
\hline
\end{tabular}

\section{TLC (THIN LAYER CHROMATOGRAPHY)}

Rf values of all Samples are mentioned in the Table are as follows

Table 2 Observations in Visible light After placing in Iodine Chamber

\begin{tabular}{|c|c|c|c|c|c|c|}
\hline \multirow{2}{*}{ Sr No } & \multirow{2}{*}{ Color } & \multicolumn{5}{|c|}{ Rf Value } \\
\cline { 3 - 7 } & & $\begin{array}{c}\text { Shunthi } \\
\text { Extract }\end{array}$ & $\begin{array}{c}\text { Lab } \\
\text { Prepared }\end{array}$ & Sample 1 & Sample 2 & Sample 3 \\
\hline 1 & Yellow & - & 0.13 & - & - & - \\
\hline
\end{tabular}




\begin{tabular}{|c|c|c|c|c|c|c|}
\hline 2 & Yellow & 0.47 & - & - & 0.47 & - \\
\hline 3 & Yellow & 0.63 & - & 0.63 & 0.63 & - \\
\hline 4 & Yellow & 0.69 & - & 0.69 & 0.69 & - \\
\hline 5 & Yellow & 0.76 & 0.76 & - & 0.76 & 0.76 \\
\hline 6 & Yellow & 0.83 & 0.83 & 0.83 & 0.83 & 0.83 \\
\hline 7 & Yellow & 0.92 & 0.92 & 0.92 & 0.92 & - \\
\hline
\end{tabular}

\section{Discussion}

\section{Gandhaka Rasayana}

Bhavana employed in the preparation is responsible for guna vardhana and which in turn enhances the medicinal properties, even in alpa matra, potency of drug increases. The specific sweet odour is due to retension of volatile aromatic components of bhavana dravyas. Giving bhavanas results in forming uniform micronised size of the drug particles and in creating a uniform coating of the bhavana dravyas over a core of sulphur particles. Sulphur may be acting as a vehicle for uniform distribution of the extracts of herbal drugs having Rasayana properties. During Bhavana of Chaturjata, Phanta was taken as the volatile active particles present in them might escape due to excess heat In Chaturjata, the Twaka, ela, patraka and nagakeshar were taken together as in reference it is mentioned as Chaturjata itself. Haritaki, bibhitaki and aamalki were taken separately as mentioned in the reference. Sita added at last might again help to combat the ushna tikshna guna present in Gandhaka and bhavana dravyas. This also helps in fixation of dosage and administration.

\section{Market available samples of Gandhaka Rasaayana}

Three samples of Gandhaka Rasayana, for the comparative study were selected from the Ayurvedic medicinal shop. The Samples selected are prepared by respective pharmacy with same reference that is Yoga Ratnakar Rasayana adhikara. An appearance of all the three samples were different which gives the idea about their preparation.There was a color and taste variation between three samples, indicates lower concentration of bhavana dravya in these samples. 


\section{Discussion on Analytical study}

\section{Loss on drying}

The loss on drying percentage of lab prepared sample was $1.91 \%$ which shows that the moisture content was less, this might suggest that it can be stored for long time, and bacterial growth should be minimised. In Market sample 1, 2, 3 the observed values are $2.72 \%, 3.51 \%, 3.30 \%$ respectively, it shows that moisture in sample 1 is low but in sample 2 and 3 is more that means these samples cannot be stored for long time and chances of Bacteria formation are more

\section{pH}

The acidic or baic nature of the compound is determined from the $\mathrm{pH}$ value. The $\mathrm{pH}$ of lab prepared Gandhaka Rasayana samples is $4.45 \%$ and other three samples are 5.6, 4.42 and 6.4 respectively. It shows that lab prepared sample and sample 2 are acidic in nature Due to Bhavana dravyas present in it, and Sample 3 is might not triturated with any bhavana dravya.

\section{Ash Value}

Ash value suggest the inorganic matter present in the sample and thus suggest about its shelf life. Ash value of lab prepared Gandhaka Rasayana is $25 \%$ and Samples 1, 2, 3 are $35.5 \%, 39 \%, 33 \%$. It shows that Lab prepared sample contains less inorganic matter and others contain more inorganic matter.

\section{Sulphur Percentage}

In lab prepared sample sulphur percentage is $13.74 \%$ and in samples 1, 2, 3 are $53.51 \%, 19.24 \%, 70.08 \%$ respectively. The percentage of sulphur is higher because the concentration of bhavna dravya is less. The percentage of our lab prepared samples is low because the gandhaka was levigated 72 times with swaras, kwatha of different bhavana dravya. This might show lab prepared and sample 2 are subjected to bhavana because sulphur percentage is low because sulphur might have combined with herbal components in herbal dravyas used for bhavana and samples 1 and 3 have much percentage of sulphur that means sulphur have not levigated with Bhavana dravyas.

\section{Water soluble Extract}

Water soluble extract values of lab prepared Gandhaka Rasayana sample was $48.84 \%$ and samples 1, 2, 3 are $25.95 \%$, $34.10 \%, 6.79 \%$ respectively, It shows the solubility of lab prepared sample is more than the other samples. Increased solubility in water indicates its dissolution, hence the lab prepared sample is more dissolvable than other samples.

\section{Particle size}

Particle sizes of lab prepared sample and Samples 1, 2, 3 are $<0.841 \mathrm{~mm},<1.41 \mathrm{~mm}$, $<1.68$, and $<1.00$ respectively. It shows the difference between lab prepared and market available samples particle sizes. Less particle size of the sample indicates, the particles became smaller due to levigation process, and it is helpful in absorption of that particles. Smaller particles dissolve and absorb more quickly. It might have property to reach up to cellular level. In other samples it is more, that indicates these samples are not well triturated or bhavana not being given to these samples, because higher the levigation process, smaller will be the particle size. 
Discussion on TLC ( Thin Layer Chromatography)

TLC of such drugs like Gandhaka Rasayana is not feasible because of presence of multiple herbs in preparation however, standard was taken as Shunthi and with Shunthi all the four samples were compared. Lab prepared samples show unidentified spots that may corresponds to bhavana dravya present in Gandhaka Rasayana, and other spots corresponds to various bhavana of Shunthi. However other three samples show more or less spots of shunthi only.

\section{Conclusion:}

Gandhaka Rasayana is the Herbo-mineral preparation with Shuddha Gandhaka as its main ingredient processed with various bhavana medias. Own Prepared Gandhaka Rasayana have parameters as

Loss on drying - $1.91 \%$

$\mathrm{pH}-4.45$

Ash value $-25 \%$

Sulphur percentage $-13.74 \%$

Water soluble extract $-48.84 \%$

Particle size $-<0.841 \mathrm{~mm}$

It explains the usefulness of Bhavana, levigation process as $50 \%$ of free sulphur converts into only $13.74 \%$, because levigation process converts free sulphur into compound form.

Many pharmacies prepare it according to their ease and feasibility, they write the reference on labeling but they don't prepare it by proper method.
It is necessary to do further study on this topic to have corrective measures in the process and this study will pave a way to have standard parameters for pharmacological characterization of 'Gandhaka Rasayana' a polyherbal drug.

\section{References:}

1. Vagbhatacharya 'Rasa Ratna Sammucchaya' edited by Ambikadatta Shastri, fifth edition, Choukhamba Sanskrit Series, Varanasi - 221001 (India) 1976.

2. Madhava Upadhyaya ' Ayurved Prakash' edited by Gularaj Sharma, Third edition, Choukhamba Bharati Academy, Varanasi 221001 (India), 1987.

3. Sadanand Sharma, Rasa Tarangini, with Prasadani Commentary by Shree Haridatta Shastri, Motilal Banarasidas, Delhi-7, edition-11, 1979.

4. Acharya Charaka, Charaka Samhita, with Aayurved Dipika Commentary by Chakrapaani. Choukhamba Sanskrit Sansthan, Varanasi-1, edition-5, 2001.

5. Acharya Sushruta, Sushruta Samhita, with Nibandhasangraha commentary by Dalhana, Choukhamba Orientalia, Varanasi1, edition-8, 2005.

6. Vagbhata, Ashtanga Sangraha, with Shashilekha commentary by Shree Indu, Choukhamba Sanskrit Series office, Varanasi-1, edition-1, 2006.

7. Vagbhata, Ashtanga Hridaya with Sarvang Sundar and Ayurved Rasayana commentaries, Choukhamba, Surbharati prakashana, varanasi, 1997. 
8. Sharangadhara, Sharangadhara Samhita, with Deepika commentary by shree Aadhamalla and Gudhaarthadeepika commentary by shree Kasheeram, Chaukhamba Orientalia, Varanasi-1, edition-5, 2002.

9. Yoga Ratnakaa, Chaukhamba Sanskrit Sansthan, Varanasi-1, edition-7, 2002.

10. Bhairavananda Yogee, 'Rasarnava' Hindi commentary by Tripathi I.D., post box no 8, Chaukhamba Sanskrit Series Office, Varanasi, 2001.

11. Dattaram Chowbey, Brihad Rasa Raja Sundar, Chaukhamba Orientalia, Varanasi-1, edition-6, 1981.

12. Acharya Bhavamishra, Bhavaprakasha Nighantu, Chaukhamba Bharati Academy, Varanasi-1, Reprint edition, 2002.

13. Acharya Bindu, Rasapaddhati, Chaukhamba Orientalia, Varanasi-1, edition-1, 1987.

14. Raja Radhakanta Deva, 'Shabdakalpadruma', Third edition, post box. 8. Chaukhamba Sansri series office, Varanasi 221001 (India), 2001.

15. Bhoodeva Mukharjee, 'Rasa Jala Nidhi', Vol- I-V, Chaukhamba Publishers, Varanasi, 2001.

16. Chudamani Mishra, 'Rasa Kamdhenu', Hinfdi commentary by Sharma G.R. and Sharma S.K., Chaukhamba Orientalia, Varanasi, 1999.

17. Dhamankar and Puranik, Ayurvediya Aushadhikaran, Part-I and Part-II, Shree Dhootpapeshwar Ayurved Pvt. Ltd. Panvel, Raigad.
18. Dhanwantari, Dhanwantari Nighantu, Chaukhamba Orientalia, Varanasi-1, edition-3, 2002.

19. Gopalkrishna Bhatta, Rasendra Sara Sangraha, Chaukhamba Orientalia, Varanasi-1, edition 2, 1998.

20. Rasopnishad qoted in Ayurvediya Rasashastra, Prof. Siddhinandan Mishra.

21. Somadeva, 'Rasendra Chudamani', Hindi commentary by Mishra S.N., Chaukhamba Orientalia, Varanasi, 1999.

22. Sharma P.V., Dravyaguna Vidnyan Vol-II, fifth edition, Chaukhamba Sanskrit Sansthana, Varanasi.

23. Chandrabhushana Jha, Ayurvediya Rasashastra, Chaukhamba Surbharati Prakashana, Varanasi, 2000.

24. Pandit Narhari, Raja Nighantu edited by Dr. Indradev Tripathi, Third edition, Chaukhamba Prakashana, Varanasi, 2003.

25. Shyamsundar Vaishya, Rasayanasara, Shyamsundar Rasayanshala Prakashana, Gayghat, Varanasi, edition- 5.

26. Shyamrao Dhondopanth Kulkarni, Aayurvediya Rasaushadhi Nirmaana, Continental Prakshana, Pune-30, edition-1, 1981.

27. Nagarjuna, Rasendra Mangal, Chaukhamba Orientalia, Varanasi-1, Edition-1, 2002.

28. Bhairavokta, 'Aanandakanda', with Siddhiprada Hindi commentary by Prof. Siddhinandana Mishra, Chaukhamba Orientalia, Varanasi, Edition-1, 2008.

29. Vd. Datta Ballal Borkar, 'Rasachandashu', Edited by Dr. Ramesh Babu, Hindi translation by Prof. S. S. Savarikar, Prakashak 
Kendriya Aayurved evam Siddha Anusandhan Parishad, Delhi, 2011.

30. Sahasrayoga by Dr. Ramnivas Sharma, Dr. Surendra Sharma, Chaukhamba Sanskrit Pratishthan, Delhi, 2012.

31. Vangasena, Vangasen Samhita, Hindi Translation by Dr. Rajivkumar Rai, edited by Dr. Ram
Kumar Rai, Prachya Prakashan, Varanasi, 2010.

32. Rasavaidya Naganida Chaganlal Shah, Bharat Bhaishajya Ratnakar, First edition

33. Ayurvedic Pharmacopoea of India, Part I and Part II, Ministry of Health and family welfare, GOI, Published by The controller of publications civil lines, Delhi, 2008.

\section{Cite this article:}

\section{Comparative study of own prepared and market available} Samples of Gandhaka Rasayana

\section{Nade Tejaswini Adappa, S.L.Dasari}

Ayurlog: National Journal of Research in Ayurved $S_{\text {cience-2017; 6(1): 1-8 }}$ 